\title{
The Effect Of Earnings Management And Corporate Governance On The Cost Of Equity Capital In Listed Manufacturing Industries In Indonesia
}

\author{
Wiwik Utami ${ }^{1}$, Rieke Pernamasari ${ }^{2}$ \\ \{wiwik.utami@mercubuana.ac.id ${ }^{1}$, rieke.pernamasari@mercubuana.ac.id ${ }^{2}$ \} \\ Universitas Mercu Buana, Indonesia ${ }^{12}$
}

\begin{abstract}
The population was manufacturing companies listed in Indonesia Stock Exchange, sample was selected by purposive method based on annual report 2011-2013. Earnings management was measured based on real earnings management approach, used abnormal cash flow and abnormal expense. As a proxy of corporate governance, we used the amount of independent audit committee and audit committee meeting frequency. Cost of equity capital was measured by modified Ohlson model. The results of the study showed that the amount of independent audit committee and audit committee meeting frequency has no influence on the cost of equity capital. Earnings management which was measured based on abnormal CFO has no influence to the cost of equity capital, whereas abnormal expense has an influence on the cost of equity capital. This reflects that investors consider abnormal expense in calculating the cost of equity capital expectations.
\end{abstract}

Keywords: Independent audit Committee, meeting frequency, abnormal Expense, Abnormal CFO, Cost of equity Capital

\section{Introduction}

Earnings quality is an issue that is considered important by investors, creditors and other stakeholders. Financial statement information is regarded as fundamental information which must be held before taking a decision. Profit is the information that becomes the center of attention, so that if the quality of earnings presented are not reliable then stakeholders will not believe and the one in the decision. Earnings quality can be said to be high when earnings are reported to be used by users to make decisions, and can be used to predict earnings, stock price or future stock returns.

In the global economic conditions, the company can fulfil the needs of funding from various parties in the global financial and capital market. Rational investors will give a price on agency risk which reflected the level of cost of equity capital. Agency risk can be grouped into two types, namely moral hazard and adverse selection. To reduce the risk company should applied good corporate governance (1).

To improve the quality of earnings company, implement good governance or better known as good corporate governance (GCG). Through the implementation of GCG can provide guide and direction to the owners and management to achieve corporate objectives effectively. If the management is committed to adhere to the agreed governance, the quality of 
earnings will rise and the investor will provide a further consequence of the appreciation in the form of trust so as to reduce the cost of equity capital.

The Indonesian Institute for Corporate Governance (IICG) is an organization aims to promote good governance practices in Indonesia and assist companies in implementing corporate governance. Table 1 showed the data on the number of companies that are willing assessed its governance practices by IICG from 2001 to 2011.

Table 1. The participant of IICG survey on GCG implementation in the period 2001-2011

\begin{tabular}{rlll}
\hline Year & $\begin{array}{l}\text { Listed } \\
\text { Company }\end{array}$ & Private Company & $\begin{array}{l}\text { Total } \\
\text { Participants }\end{array}$ \\
\hline 2001 & $\mathbf{5 2}$ & - & 52 \\
2002 & $\mathbf{1 0}$ & 22 & 32 \\
2003 & $\mathbf{7}$ & 23 & 30 \\
2004 & $\mathbf{1 0}$ & 12 & 22 \\
2005 & $\mathbf{2 2}$ & 4 & 26 \\
2006 & $\mathbf{1 7}$ & 8 & 25 \\
2007 & $\mathbf{1 1}$ & 10 & 21 \\
2008 & $\mathbf{1 4}$ & 6 & 20 \\
2009 & $\mathbf{1 8}$ & 8 & 26 \\
2010 & $\mathbf{1 6}$ & 17 & 33 \\
2011 & $\mathbf{2 5}$ & 15 & 40 \\
\hline
\end{tabular}

At the beginning of the survey conducted in 2001 there were 52 companies. However, the amount of participation in the following years was decrease. The number of listed company participant was also relatively small compared with the number of listed companies in Indonesia Stock Exchange are 420 companies.

Research on the influence of corporate governance mechanism against the cost of equity has been carried out by Ashbaugh, Collin, and La Fond (2004) using a sample of 444 companies in the year 1996-2000 (2),(3). Governance (CG) proxy with four dimensions, namely the quality of financial information, the audit committee, the ownership structure and the right stakeholders. The study concludes that companies that have an independent audit committee that more have a lower cost of equity.

Research on the quality of the profit to the cost of equity has been carried out (4). The study was conducted by examining the influence of the quality of earnings and voluntary disclosure of the cost of equity. As a result, using the measurement of the quality of accrual, discretionary accrual, earnings variability and the common factor as a proxy for earnings quality is having a negative effect on the cost of equity.

Subsequent research Siswardika and Sylvia (2012), which examined the relationship of corporate governance on the quality of earnings and corporate governance as well as the quality of the relationship of profit to the cost of equity in manufacturing companies (5). The result showed that the board of commissioners did not have a significant effect on the quality of earnings, while the audit committee has a negative effect on the quality of earnings. Earnings quality and audit committee positively affects the cost of equity while the board of directors and audit quality does not influence on the cost of equity.

Based on previous studies shown inconsistent results cause of difference proxies related to corporate governance and earnings management. The authors were interested to find empirical evidence on the effect of earnings management and corporate governance on the cost of equity capital which difference proxy. Audit committee has importance role to control 
and monitor management activities. The amount of independent audit committee and the frequency of their meeting will be better as a proxy of good corporate governance. There are some proxy of earnings management, and real earnings management is the latest method. The research question, do earnings management and corporate governance affect the cost of equity capital?

\section{Literature Review}

\subsection{Agency theory}

Agency theory or also in the literature called "contracting theory" is a theory derived from the firm theory proposed by Ronald Coase (1937) (6). The theory aims to explain that the company as a collection of contracts or agreements between the various parties. Each party is assumed to only pay attention to the satisfaction (utility) and its own interests. Thus each individual realize that the other party would take an action that will maximize the satisfaction of each. Each party is also aware that the level of their welfare depends on the company's ability to compete with other companies. Therefore, to reduce conflict, then each party voluntarily will make agreements / contracts that specify the rights and obligations of each party against the company and also restrict the actions that can reduce the value of the company.

Jensen and Meckling (1976) showed that the contract between shareholders and managers as an agency relationship, in which shareholders are the principal that gives authority to the manager as an agent to manage the company on behalf of shareholders (7). Managers assumed to obtain satisfaction in the form of money (pecuniary benefits) and satisfaction in the form of non-financial pecuniary benefits, for example relax in employment, financial waste companies for their own interests.

Relating to the agency relationship, the accounting plays an important role as a means of monitoring the company, so the contract costs can be minimized. Lambert (2001: 4) says that the relationship cause problems incentive (incentive problems), and agency theory used in accounting research to answer two basic questions, namely "(1) how do features of information, accounting, and compensation system Affect (reduce or Make worse) incentive problems, and (2) how does the existence of incentive problems affect the design and structure of information, accounting, and compensation system? (1)

\subsection{Earnings management}

Copeland (1968: 10) defines as earnings management, "some ability to increase of net income or decrease reported at will". This means that the earnings management businesses include the management to maximize or minimize the profit, including income smoothing accordance with the wishes of management. Earnings management is done to influence the perception of investors, particularly to influence the decision to buy shares of the company and affect the value of the company. Nelson et al. (2000: 1) examine the earnings management practices conducted by the management in the United States and identify the cause of the auditor let profit management without being corrected (8). Using data 526 cases of earnings management are obtained by a survey on public accounting firm that is classified as the big 
five is concluded that: (1) $60 \%$ of the sample do business profit management resulted in increased income for the year (current year), the remaining 40\% impact on the profit; (2) earnings management the most frequent are those related to reserves (reserve), then in order of frequency of occurrence is, revenue recognition, the merger of business entities (business combination), intangible assets, fixed assets, investments, leasing, compensation ; and (3) The number of cases received correction (adjustment) of the auditors as much as $43 \%$, the remaining $57 \%$ of cases are not corrected, the reason $22 \%$ of cases do earnings management in a category that is permitted by the accounting standards, $18 \%$ of the cases in which the auditor has not received evidence compelling (convincing evidence), and $17 \%$ of cases for other reasons, for example because the amount is not considered material.

Earnings management is a topic that has received much attention in the study of accounting. However, most previous earnings management research focused only on accrualbased earnings management techniques (accrual-based earnings management), but the company uses a variety of techniques earnings management. In fact, the survey results of Graham et al. (2005) in Daniel and Paul (2008) showed that the top managers tend to prefer the real earnings management rather than accrual-based earnings management to achieve the profit target (9),(10). Whereas in other studies Cohen et al (2005) showed that managers have switched from accrual-based earnings management to the real earnings management after a period of Sarbanes-Oxley Act (SOX) in order to avoid detection by auditors and regulators (11).

\subsection{Cost of Equity Capital}

The cost of capital is the rate of return that should be generated by the company on investment projects to maintain the value of the stock market. Capital costs can also be regarded as the required return by funders to invest their funds into the company. Capital costs are calculated on the basis of long-term funding sources available to the company. There are four long-term funding sources, namely: (1) long-term debt; (2) preferred shares; (3) ordinary shares; and (4) of retained earnings. Cost of long-term debt is the cost of debt after taxes at this time to obtain long-term funding through loans. Cost of preferred stock is an annual preferred stock dividend divided by the sale of preferred stock. Ordinary share capital expense is the large rate used by investors to discount the expected dividends received in the future (expected future dividends).

Botosan and Plumlee (2002) investigated the relationship between the expected cost of equity capital by three types of disclosures (12): (1) annual report; (2) Quarterly and other published reports; and (3) investor relations. Cost of equity capital is measured by measuring four alternatives: (1) the dividend discount formula; (2) EBO models; (3) Gordon Growth models; and (4) a model of Gebhardt et al. (1999). The sample used includes 3620 companies per year of observation, covering the reporting of year 1985/1986 until 1995/1996, and covers 43 industry sectors. Assuming that the dividend discount model of measurement is the most ideal formula, it was concluded that the model EBO is the best, because the cost of equity capital is generated close to the value of the dividend discount formula.

\subsection{Hypothesis development Corporate governance and the cost of equity capital}


As described in the literature review, the existence of better corporate governance will generate less cost of equity capital through reducing the cost of monitoring conducted by the investor. Ashbaugh, Collin, and La Fond (2004) supports the evidence that companies that have an independent audit committee will more have a lower cost of equity [2].

H1: Corporate Governance which was proxy by the proportion of independent audit comittees negative effect on the cost of equity capital.

H2: Corporate Governance which was proxy by the activity of the audit committee meeting has negative influence on the cost of equity capital.

\subsection{Real earnings management and the cost of equity capital}

In general, investors use earnings figures in the financial statements as a basis for analyzing the business. But the tendency to see these earnings figures to encourage the emergence of conflict of interests between management and investors that cause behavioral aberrations. One form is the presence of earnings management element of subjectivity in the selection of management policies, it can increase investor uncertainty over investment risk. The earnings information which contain management earnings results showed in financial reports tend to be biased utilized by investors in analyzing the company's performance in the future. So, to compensate for any risk on their investment, investors will increase the required rate of return and will ultimately increase the cost of capital for the company.

Dechow et al. (1996), examines the causes and consequences of earnings manipulation, where one goal is to determine the extent of earnings manipulation impact on the cost of capital. The higher the level of earnings management showed the higher risk of stock returns and consequently investors will raise the rate of cost of equity capital (13).

Real earnings management can be defined as the management measures that deviate from normal business practices conducted with the main objective to achieve the profit target (10),(14). Real earnings management can be done with three (3) ways:

a. manipulation sales

Manipulation of the sale is an effort to increase sales on a temporary basis in a given period by offering discount prices on excessive product or provide more lenient credit requirements. This strategy can increase sales volume and profit of the current period, assuming a positive margin. But giving price discounts and credit terms are more lenient will reduce the cash flow of the current period.

b. The decline in dicretionary expenditures

Companies can reduce discretionary expenditures such as research and development expenses, advertising, and selling, administrative and general especially in the period in which such expenses are not directly lead to revenue and profit. This strategy can increase profit and cash flow this time period, but with the risk of lowering the cash flows coming period.

c. Excessive production (over production)

To increase profits, manager of the company can produce more than is necessary on the assumption that the higher production rate will cause the fixed costs per unit of product is lower. This strategy can reduce the cost of goods sold and increase operating profit. 
Earnings management action is measured by the value of the cash flow abnormalities and abnormal production costs, this study uses a model used in the study, namely (14):

a) The level of abnormal operating cash flow

$$
\frac{\text { CFO }_{i t}}{\text { Assets }_{i}, \mathrm{t}-1}=\frac{k 1 \quad 1}{\text { Assets }_{i}, \mathrm{t}-1}+\frac{k 2 \quad \text { Sales }_{i t}}{\text { Assets }_{i, t}-1}+\frac{k 3 \Delta \text { Sales }_{i t}}{\text { Assets }_{i, t}-1}+\varepsilon_{i, t}
$$

Abnormal operating cash flow is an absolute value of the actual CFO CFO minus normal levels calculated from the regression model coefficients.

b) The level of abnormal production costs.

Cost of production is determined from the total COGS plus a change of inventories during the year.

$$
\frac{\text { PROD }_{i t}}{\text { Assets }_{i}, \mathrm{t}-1}=\frac{k 1 \quad 1}{\text { Assets }_{\mathrm{i}, \mathrm{t}-1}}+\frac{k 2 \quad \text { Sales }_{i t}}{\text { Assets }_{\mathrm{i}, \mathrm{t}-1}}+\frac{k 3 \Delta \text { Sales }_{i t}}{\text { Assets }_{\mathrm{i}, \mathrm{t}-1}}+\varepsilon_{\mathrm{i}, \mathrm{t}}
$$

Abnormal production costs is an absolute value of the actual production costs reduced levels of normal production costs were calculated from the regression model coefficients.

Where :

CFOit: Operating cash flow of firm $i$ in year $t$

PRODit: Cost of production of firm $i$ in year $t$, determined by COGSit $+\Delta$ Invit

Salesit: The net sales of the company $i$ in year $t$

Salesi $\Delta \mathrm{t}-1$ : Growth of net sales of the company $\mathrm{i}$ of year $\mathrm{t}-2$ to $\mathrm{T}-1$

Salesi $\Delta \mathrm{t}$ : Growth in net sales of the company $\mathrm{i}$ of year $\mathrm{t}-1$ to $\mathrm{t}$

Assetsi, t-1: Total assets of company $i$ in year $t-1$

H3: Real earnings management which was proxy by abnormal cash flow has negative effect on the cost of equity capital

H3: Real earnings management which was proxy by operating expense has negative effect on the cost of equity capital

\section{Research Methods}

The object of the research are corporate governance, real earnings management, and the cost of equity capital. The data was collected in the annual financial statements for the years 2011-2013. The design of the study is a causal explanation or explanatory research. Data were collected and analyzed using a data pool, which is a combination of time series data with the data cross sectional.

\subsection{Population and Sample}

The population in this study is the manufacturing sector issuers listed on the Indonesia Stock Exchange. The listed company category in the manufacturing sector are: Basic and 
Chemical Industry; Various Industries; Food and Beverage Industry. Sampling method was using purposive sampling, which is based on availability of the annual report.

\subsection{Operationalization variables}

1. Corporate governance

In this study used a proxy for the number of independent audit committees and audit committees activity based on the frequency of meetings in a year.

2. Real earnings management

The Proxy of real earnings management is abnormal Cash Flow from Operation, abnormal discretionary expenses which is calculated based on the formula (14).

3. The cost of capital is the rate of return that should be generated by the company on investment projects to maintain the value of the stock market. Cost of capital can also be regarded as the required return by funders to invest their funds into the company

\subsection{Size as a control variable}

Several previous studies indicate that the size of the company has a significant influence on the cost of equity capital (15). Size companies use a proxy for market value, ie the number of shares outstanding in the announcement of the financial statements. The size of the company given the symbol (LnSIZE).

\subsection{Analysis Method} follows:

The analytical method used is multiple regression analysis with the regression model as

$$
\mathrm{Y}=\alpha 0+\alpha 1+\alpha 2+\mathrm{X} 1+\mathrm{X} 2+\mathrm{X} 3+\alpha 3 \mathrm{LnSize}+\varepsilon 1
$$

\section{Results And Discussion}

Based on Table 1 it can be seen that the number of samples that qualify according to the criteria as much as 183 observations, which is a data pool for out 2011 to 2013 . The average abnormal cash flow is $-0.11 \%$, with a maximum value of $116 \%$. Figures abnormal cash flow relative small, which means that for 3-year fluctuations in operating cash flow is relatively stable.

Abnormal average expense $-0.19 \%$, with a maximum value of $119.5 \%$. Abnormal numbers are also relatively low expense and less volatile. Abnormal cash flow and expense seems to have a similar pattern, but it appears that abnormal expense is more varied than the abnormal cash flow jikan seen from the standard deviation of the data. Cost of equity capital has a minimum value of $-19.91 \%$ and a maximum of $62.69 \%$, with an average value of $9.88 \%$. Rat average capital cost of $9.88 \%$ is relatively low when compared with the level of mortgage interest rates ranging from $12 \%-14 \%$. This means that the rate of yield investors demand is relatively low, which could also indicate that investors have the perception that the stock 
investment in companies that have applied GCG has a relatively lower risk compared with the issuer that has not been applying GCG. Due to the relatively low risk then the rate of return required to be at a moderate level.

Table 2. Descriptive statistics.

Descriptive Statistics

\begin{tabular}{|l|r|r|r|r|r|}
\hline & \multicolumn{1}{|c|}{ N } & Minimum & \multicolumn{1}{c|}{ Maximum } & \multicolumn{1}{c|}{ Mean } & Std. Deviation \\
\hline Abnormal CFO & 183 & -.49286 & 1.16218 & -.0011647 & .18637100 \\
Abnormal Expense & 183 & -.19169 & 1.19550 & -.0019743 & .21724285 \\
Biaya modal & 183 & -19.91 & 62.69 & .9887 & 6.57545 \\
Frekuensi rapat & 183 & .00 & 37.00 & 5.7978 & 5.76629 \\
Komite Audit Independen & 183 & .00 & 1.00 & .5339 & .26809 \\
aset & 183 & 10583.00 & 50770251.00 & 3699289.989 & 7390293.258 \\
Valid N (listwise) & 183 & & & & \\
\hline
\end{tabular}

\subsection{Hypothesis testing}

The test results using plot diagram shows the result that the data are not distributed normally. It can be seen from the data distribution that is far from the diagonal line. To improve the distribution of the data, the measurement transform into a log 10 or Ln natural. Consider that the abnormal data Abnormal expense cash flow and there are many variable with a negative value then the first step is to create absolute value of these variables, then a new transformation was done. The result of coefficient regression was reveal in table 3 .

Table 3. Regression coefficient

\begin{tabular}{lllllllll}
\hline \multirow{2}{*}{ Model } & & \multicolumn{2}{l}{$\begin{array}{l}\text { Unstandardized } \\
\text { Coefficients }\end{array}$} & $\begin{array}{l}\text { Standardized } \\
\text { Coefficients }\end{array}$ & T & Sig. & \multicolumn{2}{c}{ Collinearity Statistics } \\
\hline & & B & Std. Error & Beta & & & Tolerance & VIF \\
\hline 1 & & & & & -3.001 & $\mathbf{. 0 0 3}$ & & \\
& (Constant) & -6.696 & 2.231 & & 2.161 & $\mathbf{. 0 3 2}$ & .913 & 1.095 \\
& log aset & .799 & .370 & .165 & -.404 & $\mathbf{. 6 8 7}$ & .941 & 1.062 \\
& LnabsCFO & -.083 & .205 & -.030 & -2.402 & $\mathbf{. 0 1 7}$ & .937 & 1.067 \\
& LnabsEXP & -.615 & .256 & -.181 & -.412 & $\mathbf{. 6 8 1}$ & .976 & 1.025 \\
& Meeting & -.019 & .047 & -.030 & 1.209 & $\mathbf{. 2 2 8}$ & .918 & 1.089 \\
\hline
\end{tabular}

Independent audit committee has not affect the cost of equity capital, which the independent committee has $t$ value 1,209 with a significance level of 0.228 (above $\alpha=0.05$ ). as well as the results of an audit committee meeting frequency test does not affect the cost of 
equity capital, where the frequency of audit committee meetings have $t$ value -0142 with a significance level of 0.681 (above $\alpha=0.05$ ). These results are not in accordance with the research, where the existence of better corporate governance will result in a lower cost of equity through a reduction in the cost of monitoring conducted by the investor [2]. Variable independent committee has no significant effect on the cost of equity capital. Its suppose that investors tend to see the supervisory function less effectively. This could have been due to the lack of independence of the commissioner because of the relationship of independent committee members having affiliation with the company as well as the disclosure of the definition of independence is lacking in the annual report. The existence of an independent committee also deemed to be limited to the observance of the regulation of capital markets and has not been used as an independent oversight function (16).

The frequency of meetings of the audit committee has no significant effect on the cost of equity capital. This result can be caused by many things, the first investors have not seen the effectiveness of the existence of an audit committee that has been disclosed in the annual report and the second companies are likely disclosure of information is just fine related to the effectiveness of the audit committee, including the frequency of audit committee meeting in the annual report. Thus the first hypothesis is not proven.

Abnormal expense showed significantly influence of the cost of equity capital, which has the abnormal expense amounted to $-2402 \mathrm{t}$ with a significance level of 0.0172 (under $\alpha=$ 0.05). Referring to the research, where the higher the level of earnings management showed the higher risk of stock returns and consequently investors will raise the rate of cost of equity capital [10]. In other words abnormal relationship accrual (management) earnings and the cost of equity capital have a positive relationship. Results of this study provide empirical evidence of a negative relationship, so it does not support previous research. Given that at the time of regression analysis performed and the absolute transformation Ln then these empirical findings can not infer the direction of the relationship. It can be explained is that there is empirical evidence that abnormal expense expectations affect the cost of capital by investors. There is an element of subjectivity in the selection of management policies, it can increase investor uncertainty over investment risk. Here investors see loads as an influence on the cost of equity capital.

While the CFO abnormal test results do not affect the cost of equity capital, in which abnormal CFO has t -0404 with a significance level of 0687 (above $\alpha=0.05$ ). These results are certainly contrary to previous studies, namely to compensate for any risk on their investment, investors will increase the required rate of return and will ultimately increase the cost of equity capital for the company. But on this result earnings management proxy through the stream does not impact the cost of capital. Where investors do not see the current effect on the cost of capital. Thus the second hypothesis proved to abnormal expense.

\subsection{Conclusions And Recommendations}

Based on the results of testing that has been done, it can be concluded as follows:

a. The effectiveness of the independent committee and audit committee meeting frequency as part of the internal mechanism of corporate governance has no effect on the cost of equity capital. These results indicate that the presence of the independent committee and audit committee's activities have not been effective.

b. Abnormal cash flow as a proxy of earnings management has not affected the cost of equity capital. This means that real earnings management does not affect the cash flow expectations of investor. 
c. Abnormal expense affect the cost of equity capital. This reflects that investors consider abnormal expense in calculating the cost of equity capital expectations.

\subsection{Suggestion}

This study only uses independent committee and audit committee meeting frequency as an element of good corporate governance (GCG). Other proxies can be used as a measure of the effectiveness of internal mechanisms GCG to see its effect on the cost of equity capital. As for the real earnings management, proxy abnormal production can be done to see its effect on the cost of equity capital.

\section{References}

1. Magee RP. Discussion of "Contracting theory and accounting." J Account Econ. 2001;32(1-3):89-96.

2. Ashbaugh, H., Johnstone, K. M., Warfield T. "Corporate Reporting on the Internet", Accounting Horizons. 1999. 241-257 p.

3. Skaife HA, Collins DW, LaFond R. Corporate Governance and the Cost of Equity Capital. SSRN Electron J. 2011;(December).

4. Francis, J., D. Nanda dan PO. "Voluntary Disclosure, Earnings Quality and Cost of Capital. Journal of Accounting Research 46 (1). 2008. p. 53-99.

5. Susanto S, Siregar SV. Corporate Governance, Kualitas Laba, Dan Biaya Ekuitas: Studi Empiris Perusahaan Manufaktur Di Bursa Efek Indonesia Tahun 2009. J Keuang dan Perbank. 2012;14(2):49-68.

6. Barney, Jay B. and OW. Organizational Economics. Jossey-Bass Publishers, San Francisco, London. 1986;

7. Jensen MC, Meckling WH. Theory of The Firm: Managerial Behavior, Agency Costs and Ownership Structure. J financ econ [Internet]. 1976 [cited 2019 Jun 26];3:305-60. Available from: http://117.211.153.211:8001/jspui/bitstream/123456789/335/1/1-s2.00304405X7690026X-main.pdf

8. Nelson, M.W., J.A Elliot and R. T. "Where do Companies Attempt Earnings Management, and When Do Auditors Prevent It?" 2000; Available from: papers.ssrn.com

9. Cohen DA, Zarowin P. Accrual-Based and Real Earnings Management Activities around Seasoned Equity Offerings Accrual-Based and Real Earnings Management Activities around Seasoned Equity Offerings Abstract. 2008. 1-47 p.

10. Cohen, Daniel A. PZ. "Accrual-Based and Real Earnings Management Activities Around Seasoned Equity Offerings”. Journal of Accounting \& Economics. 2010;50 no.1:2-19.

11. Cohen, D. AD and TL. Cohen, D., A. Dey and T. Lys. 2005. Trends in earnings management and informativeness of earnings announcements in the pre- and postSarbanes Oxley periods. Working paper, Northwestern University. 2005;

12. Botosan, Christine A., and Plumlee MA. A Re-examination of Disclosure Level and The Expected Cost of Equity Capital. 2002;1-4.

13. Dechow PM, G. sloan richard, Sweeney AP. Causes and consequences of earnings 
manipulations : An analys. Contemp Account Res. 1996;13(1):1-36.

14. Roychowdhury S. Earnings management through real activities manipulation. J Account Econ. 2006;42(3):335-70.

15. Botosan CA. Disclosure Level and The Cost of Equity Capital, The Accounting Review. 1997;7 no. 3:323-49.

16. Siregar SV, Utama S. Type of earnings management and the effect of ownership structure, firm size, and corporate-governance practices: Evidence from Indonesia. Int J Account. 2008;43(1):1-27. 